\title{
Short Communication: Birth weight of a Holstein calf based on forefoot circumference
}

\author{
LIA BUDIMULYATI SALMAN ${ }^{1}$, WILLYAN DJAJA ${ }^{1}$, ASEP ANANG ${ }^{1}$, HENI INDRIJANI ${ }^{1}$, \\ RUHYAT PARTASASMITA ${ }^{2, \vartheta}$ \\ ${ }^{1}$ Faculty of Animal Husbandry, Universitas Padjadjaran. Jl. Raya Bandung Sumedang Km 21, Jatinangor, Sumedang 45363, West Java, Indonesia \\ ${ }^{2}$ Department of Biology, Faculty of Mathematics and Natural Sciences, Universitas Padjadjaran. Jl. Raya Bandung-Sumedang Km 21, Jatinangor, \\ Sumedang 45363, West Java, Indonesia. Tel +62-22-7797712. `email: ruhyat.partasasmita@unpad.ac.id, rp2010rikkyo@gmail.com
}

Manuscript received: 1 October 2017. Revision accepted: 13 November 2017.

\begin{abstract}
Salman LB, Djaja W, Anang A, Indrijani H, Partasasmita R. 2017. Birth weight of a Holstein calf based on forefoot circumference. Nusantara Bioscience 9: 367-370. Record of birth weight of Holstein calf can be used as consideration for selection. The purpose of this study is to determine the accuracy of birth weight based on regular measuring tape compared to Calf scale BW Tape. The records of calf's birth weight were collected from 1370 female calf birth records from PT Taurus Dairy Farm, Sukabumi. Birth weight measurements were performed by (i) measuring birth weight using Calf scale BW Tape (Nasco, Fort Atkinson, WI); (ii) predicting birth weight with regression based on the circumference of the right front toenails using regular measuring tape a day after the calf was born; (iii) weighing the calf with the scales. The results showed that the predicted birth weight of dairy cow's calves can be done by regular measuring tape with a polynomial regression equation, $Y=(-6288,6)+(1378.8 X)-\left(113.0 X^{2}\right)+\left(4.1 X^{3}\right)-\left(0.056 X^{4}\right)$, which has a deviation $0.5 \%$, and $7.4 \%$ using Calfscale BW Tape. Conclusion of this research is that predicting birth weight of dairy cow's calves using regular measuring tape is more accurate than using Calfscale BW Tape
\end{abstract}

Keywords: calf's birth weight, the circumference of the nail, measuring tape

\section{INTRODUCTION}

Birth weight of dairy calf can be used as a consideration in selection activities for maintaining management efficiency in cattle. Birth weight is the weight at the time the calf was born. However, it frequently encounters technical difficulties to weigh the right calf shortly after birth, so it is usually defined as a birth weight of a calf that weighed heavy in the span of 1 x 24 hours after birth. The good birth criteria are when the calf weighed $31.5-51.5 \mathrm{~kg}$, and had shiny fur, shining eyes with the lively condition, and soon was able to stand (Alim and Hidaka 2002).

Birth weight records will be more useful if any, because by knowing birth weight it will be used as a selection criteria in guessing the optimal weaning weight (Aryati 2008). High weaning weight will accelerate the achievement of adult body weight (Williamson and Payne 1993).

Information about calf birth weight may help breeders to evaluate genetic selection, parental nutrition and suspect future calf performance (Long et al. 2012). Many dairy farmers use birth weight registration as an indicator of the nature to minimize the risk of dystocia. In dairy cattle, the increase in birth weight is related to the occurrence of dystocia (Sieber et al. 1989; Linden et al. 2009). Cundiff et al. (1986) and Naazie et al. (1989) suggest that calf birth weight affects the variable at risk of dystocia and becomes a reference in selection of cattle breeds so that birth weight is not too large. In addition, the probability of perinatal death (death within 48 hours after birth) increased from
2.1\% for calves weighing less than $29 \mathrm{~kg}$, and to $9.6 \%$ for calves with birth weight greater than $52 \mathrm{~kg}$ (Johanson and Berger 2003). Calves with too low or too heavy birth weight have a higher chance of experiencing diarrhea than those with normal birth weight (Pare et al. 1993).

Knowing the weight of the calf body immediately after birth is most accurate by using weight scales, but sometimes the implementation is constrained by the location or limited equipment required, so it needs to be measured by other methods. A more practical alternative is by estimating birth weight based on regression equations or estimating birth weight using calf scale tape. This research aims to determine the accuracy of the calf birth weight measurement using the regression equation and calf scale tape.

\section{MATERIALS AND METHODS}

Birth weights of Holstein calf were collected from female calf birth records derived from PT Taurus Dairy Farm, Sukabumi, West Java, Indonesia and they were 1370 records. Birth weight measurement can be done using three ways, namely:

Regular measuring tape. The prediction of calf birth weight, based on the measurement of the front right toenail circumference using a regular measuring tape (Figure 1. A$\mathrm{B})$, can be done by making the regression equation by estimating equation. The equation is the polynomial regression from $\mathrm{Y}$ to $\mathrm{X}$ with the formulation as follows: $\mathrm{Y}$ 
$=\mathrm{a}+\mathrm{bX}+\mathrm{c} \mathrm{X}^{2}+\mathrm{dX}^{3}+\mathrm{eX}^{4},(\mathrm{Y}=$ birth weight $(\mathrm{kg}), \mathrm{X}=$ nail circumference $(\mathrm{cm}), \mathrm{a}=$ intercept, $\mathrm{b}, \mathrm{C}, \mathrm{d}$, and $\mathrm{e}=$ regression coefficients) (Steel et al. 1996).

Calfscale BW Tape (Nasco, Fort Atkinson, WI). Estimation of birth weight can be done by using tape for measuring the circumference of the right forefoot (Figure 1.C) (Parish et al. 2009). This tape weighs body estimation directly based on the measurement results. The unit listed on the band is lbs so it needs to be converted into $\mathrm{kg}$ ( $1 \mathrm{lbs}$ $=0.459 \mathrm{~kg}$ ).

Scales. Scales are used to determine the actual birth weight of a day old calves.

Measurement of deviation uses the following formula:

$$
\frac{|A W-E W|}{A W} \times 100 \%
$$

Note: $\mathrm{AW}=$ Actual weight; $\mathrm{EW}=$ Estimates Weight

\section{RESULTS AND DISCUSSION}

Birth weight is known closely linked with weaning weight and adult weight. Information on birth weight can be used as early selection criteria of the growth process in dairy cows. The results of the research on the measurement and prediction of calf birth weight with the number of samples of 1370 records can be seen in Table 1.

Calf birth weight of female dairy calves measured by the actual scales ranged from 30.0 to $50.0 \mathrm{~kg}$ with an average of $34.1 \pm 2.7 \mathrm{~kg}$. Body weight is in accordance with the criteria of a good calf according to Alim and Hidaka (2002) namely to have a birth weight of 31.5-51.5 kg. Similarly, Khattab et al. (2005) stated that average birth weight of Holstein is $31.84 \pm 4.58 \mathrm{~kg}$, While the observations of Salman (2014) showed that average birth weight in Breeding Center and Development of Artificial Insemination of Dairy Cow Bunikasih Cianjur is $41.88 \pm$ $3.06 \mathrm{~kg}$, and average birth weight in Central Development and Breeding Cattle Dairy at Cikole Lembang is $38.65 \pm$ $5.26 \mathrm{~kg}$, as well as the research result of Anggraeni et al. (2008) that the average birth weight of Holstein in the working area of KPSBU Lembang is about $45 \mathrm{~kg}$ (43-52 $\mathrm{kg})$.

Weight estimation using regular measuring tape is the result of estimation using regression equation. In this research, the nail circumference data are obtained then the equation using the Expert Curve was done on them. The results show that the most appropriate equation for estimating calf birth weight is the polynomial equation with the following formula: $Y=(-6288.6)+(1378.8 X)-$ $\left(113.0 \mathrm{X}^{2}\right)+\left(4.1 \mathrm{X}^{3}\right)-\left(0.056 \mathrm{X}^{4}\right)$, Where $\mathrm{Y}$ is an estimate of calf birth weight $(\mathrm{kg})$ and $\mathrm{X}$ is circumference of the right forefoot $(\mathrm{cm})$. This equation has the coefficient of determination $\left(\mathrm{R}^{2}\right)=0.997$, and se $=0.19$.

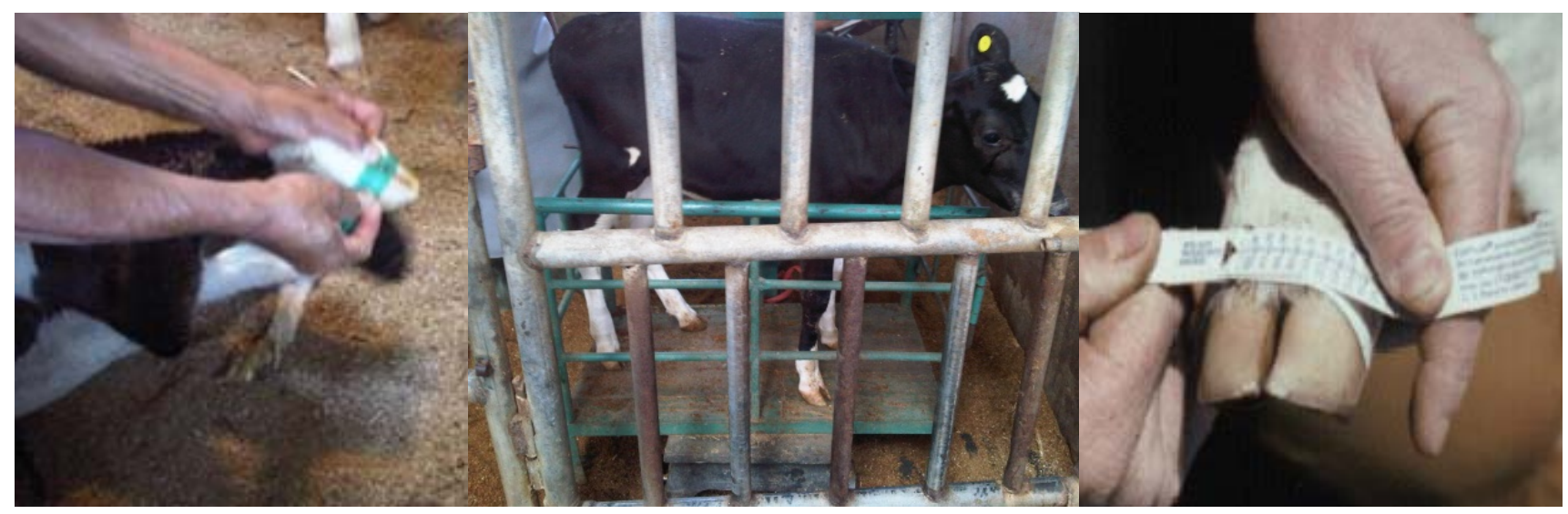

Figure 1. A-B. Measuring nail circumference with regular measuring tape and calf weighting. C. Nail circumference Tapes (Calfscale BW Tape, Nasco, Fort Atkinson, WI) and how they are used to measure

Table 1. Measurement results of forefoot circumference and estimated body weights

\begin{tabular}{lccccc}
\hline $\begin{array}{l}\text { Measurement } \\
\text { criteria }\end{array}$ & $\begin{array}{c}\text { Regular } \\
\text { measuring tapes } \\
\text { (cm) }\end{array}$ & $\begin{array}{c}\text { Calfscale } \\
\text { tapes } \\
\text { (cm) }\end{array}$ & $\begin{array}{c}\text { Actual weight } \\
\mathbf{( k g )}\end{array}$ & $\begin{array}{c}\text { Estimation of birth weight } \\
\text { with regular measuring tapes } \\
\text { (kg) }\end{array}$ & $\begin{array}{c}\text { Estimation of birth } \\
\text { weight with calfscale } \\
\text { tapes (kg) }\end{array}$ \\
\hline Minimum & 15.9 & 15.9 & 30.0 & 30.0 & 27.5 \\
Maximum & 20.1 & 19.8 & 50.0 & 49.8 & 47.5 \\
Average & 16.7 & 16.7 & 34.1 & 34.1 & 31.6 \\
SD & 0.6 & 0.5 & 2.7 & 2.6 & 2.7 \\
\hline
\end{tabular}




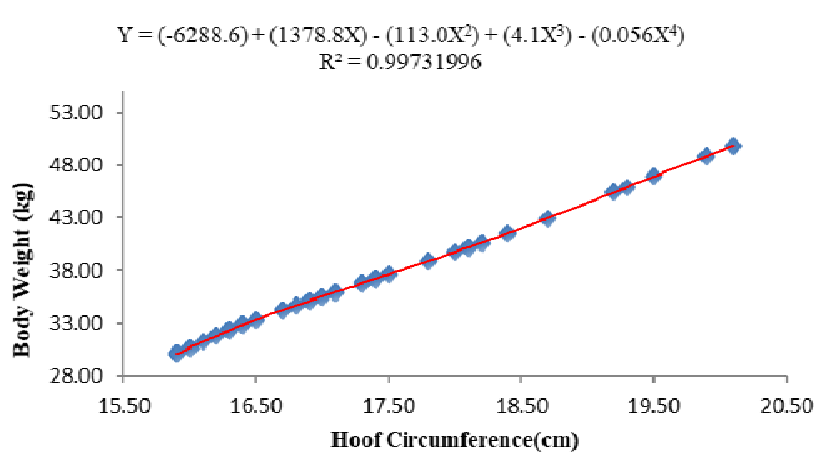

Figure 3. The curve of the polynomial regression equation of birth weight based on the circumference of the forefoot

Table 2. The deviation of birth weight based on measuring tape and actual weight

\begin{tabular}{lcc}
\hline $\begin{array}{l}\text { Measurement } \\
\text { criteria }\end{array}$ & $\begin{array}{c}\text { Regular measuring } \\
\text { tapes (\%) }\end{array}$ & $\begin{array}{c}\text { Calfscale } \\
\text { tapes (\%) }\end{array}$ \\
\hline Minimum & 0.1 & 5.0 \\
Maximum & 2.5 & 8.3 \\
Average & 0.5 & 7.4 \\
Standard Deviation & 0.3 & 0.5 \\
\hline
\end{tabular}

The polynomial regression equation has a value of determination coefficient near to one. It means that this equation has the data accuracy that is very close to the line of the regression equation. It can be said that this equation is accurate enough to be used since the coefficient of determination nears to 1 , and the smaller the value the better. Estimation of calf birth weight with Regular Measuring Tapes ranges 30.0 - $49.8 \mathrm{~kg}$, with an average of $34.1 \pm 2.6 \mathrm{~kg}$.

Estimation of calf birth weight using nail circumference tape (Calf scale BW Tape, Nasco, Fort Atkinson, WI), results in birth weight estimation of calves 27.5-47.50 kg, with an average of $31.6 \pm 2.6 \mathrm{~kg}$. This tape has a unit of weight printed directly in the ribbon so that the estimated birth weight can be immediately known. The tape is not made in Indonesia that it has lbs unit instead of $\mathrm{kg}$. The result of estimation also seems to be lower than the result of estimation using the regression equation. For better accuracy, both birth weight estimation has to be compared with actual birth weight.

The result of the measurement of birth weight deviation based on the regression equation (regular measuring tape) and on the nail circumference tape (Calf scale BW Tape, Nasco, Fort Atkinson, WI) can be seen in Table 2.

The results of this study indicate that there is a deviation on the weight (or actual birth weight) weighed using the regular measuring tape namely $0.1-2.5 \%$ with an average of $0.5 \%$. Compared to the estimated birth weight weighed using calf scale measuring tape with the result of 5.0-8.3\% and an average of $7.4 \%$, this actual birth weight number is lower.
Williamson and Payne (1978) stated that the irregularities of body weight estimation generally range from $5 \%$ to $10 \%$ of actual body weight, so both methods of estimation can be used. But if it is seen from the deviation value, the prediction of calf birth weight measured by regular measuring tape which is then converted through regression equation showed better accuracy when it is compared to the result of measurement using calf scale measuring tape.

Birth weight is an important factor in livestock productivity. Cattle with a high birth weight, above average weight, generally has a higher survival ability in passing critical period, is rapid growth and will have higher weaning weight (Salman 2014). It is concluded that the prediction of birth weight of a day old calf using regression equation resulting from measuring of right forefoot using regular measuring tape is nearer to actual birth weight ( $0.5 \%$ deviation), when it is compared to the estimation of birth weight using the calf scale measuring tape (deviation of $7.4 \%)$.

\section{ACKNOWLEDGEMENTS}

This research is conducted at the expense of Grant Assignment of Academic Leadership Grant (ALG) Research of UNPAD which is chaired by Prof. Dr. Moch. Makin, and a good cooperation with PT Taurus Dairy Farm Cicurug Sukabumi, therefore we would like to express our deepest gratitude to them, in the hope that we can still do further cooperation on another occasion.

\section{REFERENCES}

Alim AF, Hikada T. 2002. Handbook of Dairy Cattle Technology in Indonesia; Feed and Dairy Cow Management. Ministry of Agriculture-Japan International Agency-Animal Husbandry Province of West Java, Bandung. [Indonesian]

Anggraeni A, Kurniawan N, Sumantri C. 2008. Growth Performance of Holstein-Friesian Calves and Heifers in The West Area of KPSBU Lembang. Proceeding Seminar National Husbandry Technology and Veterinary. Puslitbangnak, Bogor, 11-12 November 2008. [Indonesia]

Aryati. 2008. Measurement and Recording of Reproductive and Production Capabilities. Animal husbandry Department. West Sumatra. http://www.disnaksumbar.org/content/view/200/84/16. [Indonesian]

Cundiff LV, MacNeil M D, Gregory K E, Koch R M. 1986. Between and within-breed genetic analysis of calving traits and survival to weaning in beef cattle. J Anim Sci 63: 27.

Johanson JM, Berger PJ. 2003. Birth weight as a predictor of calving ease and perinatal mortality in Holstein cattle. J. Dairy Sci. 86:3745-3755.

Julyanti S, Malensang, Komalig H, Hatidja D. 2012. Development of multiple polynomial regression model on case of marketing data. Jurnal Ilmiah Sains 12 (2): 149-152. [Indonesian]

Khattab AS, Atil H, Badawy L. 2005. Variances of direct and maternal genetic effects for milk yield and age at first calving in a herd of Friesian cattle in Egypt. Arch Tierz, Dummerstorf 48 1: 24-31.

Linden TC, Bicalho RC, Nydam DV. 2009. Calf birth weight and its association with calf and cow survivability, disease incidence, reproductive performance and milk production. J. Dairy Sci. 92:25802588.

Long NM, Collier RJ, Smith JF. 2012. Comparison of 2 methods of assessing calf birth weights in dairy calves. Journal of Dairy Science, 95(12): 7206-7209. 
Naazie A, Makarechian MM, Berg RT. 1989. Factors influencing calving difficulty in beef heifers. J. Anim. Sci. 67:324.

Pare J, Thurmond M C, Gardner I A, Picanso J P. 1993. Effect of birthweight, total protein, serum IgG and packed cell volume on risk of neonatal diarrhea in calves on two California dairies. Can. J. Vet. Res. 57:241-246.

Parish JA, Smith T, Parish JR, Best TF, Boland HT. 2009. Evaluation of four different methods of calf birth weight data collection. Anim. Sci. 25:716-721.
Salman LB. 2014. Fries Holland cattle growth model from birth to ready to breeding. [Dissertation]. Bogor Agricultural University, Bogor. [Indonesian]

Sieber M, Freeman AE, Kelly DH. 1989. Effects of body measurements and weight on calf size and calving difficulties of Holsteins. J Dairy Sci 72: 2402-2410.

Steel RGD, Torrie JH, Dickey DA. 1996. Principles and Procedures of Statistics: A Biometrical Approach. McGraw-Hill College, New York.

Williamson G, Payne WJA. 1993. Introduction to Ranch in the Tropics, $3^{\text {th }}$ ed. Gadjah Mada University Press. Yogyakarta. [Indonesian] 